\title{
ALLELOMORPHS OF THE Rh GENE C
}

\section{R. R. RACE, RUTH SANGER and SYLVIA D. LAWLER \\ Medical Research Council, Blood Group Research Unit, Lister Institute of Preventive Medicine, London}

Received 5.xii.47

IN I946 Fisher showed that three pairs of closely linked genes, $C$ and c, $\mathrm{D}$ and $\mathrm{d}, \mathrm{E}$ and e, were responsible for the $\mathrm{Rh}$ blood groups in man, each gene giving rise to a corresponding antigen on the red cell. Although the linkage is undoubtedly very close there is some indirect evidence that the genes are separable by crossing-over (Fisher and Race, I946). The genes are not sex-linked, nor partially sex-linked, nor has linkage with any other recognisable gene yet been detected.

In this paper evidence is presented for the existence of two further $\mathrm{Rh}$ genes allelomorphic to $\mathrm{C}$.

The third allelomorph at the G-c locus, called $\mathrm{C}^{\mathrm{w}}$, was recognised when an anti-Rh serum was found which agglutinated 2.5 per cent. of English blood samples. The samples which were agglutinated were shown to be of the genotypes $\mathrm{C}^{\mathrm{w}} \mathrm{c}, \mathrm{C}^{\mathrm{w}} \mathrm{C}$ and $\mathrm{C}^{\mathrm{w}} \mathrm{C}^{\mathrm{w}}$. The remaining 97.5 per cent. were of the genotypes $\mathrm{CC}, \mathrm{Cc}$ and cc (Callender and Race, I946).*

The existence of $\mathrm{C}^{\mathrm{w}}$ could have been recognised if a few hundred samples of blood had been tested for agglutination with a range of anti-C sera, for the agglutinin in some anti-C sera is in the form of pure anti-C, but in the majority it is in the form anti-C+anti- $\mathrm{C}^{\mathrm{w}}$. Blood of the genotype $\mathrm{C}^{\mathrm{w}} \mathrm{C}^{\mathrm{w}}$ or $\mathrm{C}^{\mathrm{w}} \mathrm{C}$ would have been agglutinated by the latter type of antibody but not by the former. Blood of the genotype $\mathrm{CG}, \mathrm{Cc}$ and $\mathrm{C}^{\mathrm{w}} \mathrm{C}$ would have been agglutinated by both types, and blood of the genotype cc by neither. In all, about I 5 per cent. of specimens of blood would have given discrepant results.

In the absence of other irregular anti-Rh agglutinins of the anti- $\mathrm{C}^{\mathrm{w}}$ type, which might disclose further allelomorphs at this locus, in a positive way, it seemed worth while to use the second method in an attempt to demonstrate the existence of such allelomorphs.

Samples of blood from 284 transfusion donors from the National Blood Transfusion Service, Sutton, Surrey, were tested for agglutination with the following antisera: anti-D, anti-E, anti-e, anti-c, anti-C ${ }^{\text {w }}$ and three anti-C sera. Two samples of blood gave irregular reactions

* As it is with the C-c allelomorphic genes that this paper is concerned, it is usually sufficient to give the genotype in terms of these genes only; the full genotypes involving $\mathrm{C}, \mathrm{D}$ and $\mathrm{E}$ are shown only when relevant. 
with the anti-C sera ; one was agglutinated only by the third and the other only by the first. These two blood samples were further tested with other anti-G sera as will be described later.

The father of one of the donors also possessed the same unfamiliar type of $\mathrm{C}$ as his son, and consequently the difference can with confidence be attributed to a fourth allelomorph at this locus. We are calling the gene and the antigen $\mathrm{c}^{\mathrm{v}}$; the reason for using a small $\mathrm{c}$ will be explained later.

Unfortunately the donor of the blood giving the second type of irregular reaction could not be traced, and therefore the evidence for a fifth allelomorph at this locus is somewhat incomplete.

Before describing the reactions of these two irregular types of blood, it is necessary to give some details of the behaviour of the antisera concerned with the various allelomorphs of G. It is also necessary to consider the frequencies of the $\mathrm{Rh}$ chromosomes and genes for these are involved in the argument.

\section{THE ANTIBODY ANTI-c}

This agglutinin may be made by a CC mother whose child is Cc, or it may be made by a CC recipient of blood from a cc or Gc donor.

The reactions of an anti-c serum are stronger in titration against red cells representing two doses of the $c$ gene than against red cells representing a single dose of this gene (Race, Taylor, Boorman and Dodd, 1943). The controls in fig. 4 give an example of this difference.

\section{THE ANTIBODY ANTI-C}

This agglutinin may be made by a cc mother whose child is Cc. In most cases the mother is cde/cde and the child $\mathrm{CDe} / \mathrm{cde}$, and the serum of the mother contains, as well as the anti- $\mathrm{C}$ agglutinin, the " incomplete" type of anti-D antibody. As this "incomplete" type of antibody does not agglutinate D cells in saline, the medium in which the reactions to be described are carried out, its presence may be ignored in what follows. The agglutinin may also be made by a cc recipient of Cc or CC blood.

Anti-C sera do not make a clear distinction between CC and Cc blood in an individual case, although when titrations are performed on a number of blood samples and the results are pooled the difference becomes more definite.

The discovery of the anti- $\mathrm{C}^{\mathrm{w}}$ serum lead to the recognition of the fact already mentioned, that while some anti-C sera contain pure anti-C, the majority contain anti-C+anti- $\mathrm{C}^{\mathrm{w}}$. In such mixed antibodies the anti- $\mathrm{C}^{\mathrm{w}}$ component is usually weaker than the anti-C component. The antibody is made in response to the antigen $\mathrm{C}$, the anti- $\mathrm{C}^{\text {w }}$ component being apparently a " non-specific" response to this antigen. The evidence for the "non-specific" origin of the anti- $\mathrm{C}^{\mathrm{w}}$ component in the sera now being discussed will be put 
forward. The antigen $\mathrm{C}^{\mathrm{w}}$ is not sufficiently frequent in the English population to be responsible for the number of anti-C $+\mathrm{C}^{\mathrm{w}}$ sera found. It occurs in only 2.5 per cent. of transfusion donors and of random men, and may be expected to occur in less than 5 per cent. of fathers of children with hæmolytic disease. (The increased frequency in this group is due to the disturbance caused by practically none of such fathers being dd and most of them being DD.)

It seems likely that at first the response to the antigen $\mathrm{C}$ is anti-C, and that as immunisation progresses the anti- $\mathrm{C}^{\mathrm{w}}$ component appears. This is suggested by an unpublished case of Dr Stuart Stanbury's in which the mother of a child suffering from hæmolytic disease had anti-C (and incomplete anti-D) in her serum, but no anti-Cw. The mother volunteered to be a donor of anti-Rh serum and as there were no contra-indications, prior to being bled she was given a few injections of minute amounts of her husband's blood. These injections were very effective in temporarily increasing the titre of the antibody and a most valuable antiserum resulted; but it had then become anti- $\mathrm{C}+\mathrm{C}^{\mathrm{w}}$.

The two components in an anti- $\mathrm{C}+\mathrm{C}^{\mathrm{w}}$ serum have not been separated. Absorption of such a serum by Cic cells results in the removal of both antibodies, so does absorption by $\mathrm{C}^{\mathrm{w}} \mathrm{c}$ cells (fig. I).

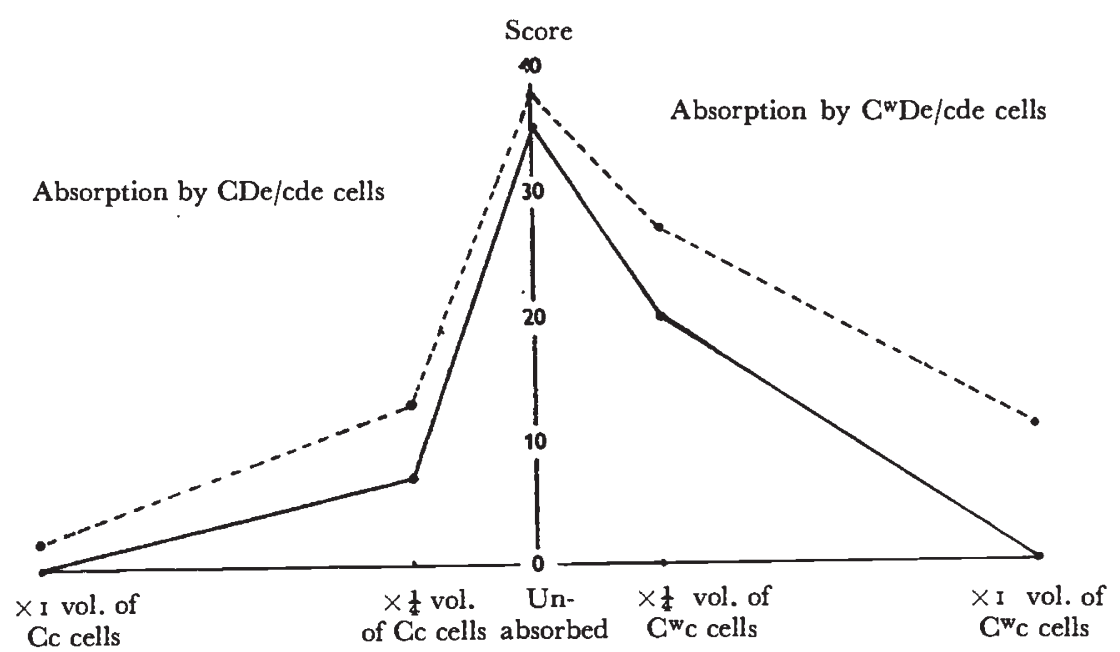

Fig. 1.-Absorption of anti-C+Cw serum ("And") by CDe/cde cells and by $\mathrm{C}^{\mathrm{w}} \mathrm{De} / \mathrm{cde}$ cells.

The representation of the result of a titration by means of a score was found convenient by Callender and Race (1946). The values used here are the same as those described in their paper, viz. 10, 8, 5, 3, 2, o for the different strength of agglutination in each tube of the titration.

- . - titration score against Cc cells

- titration score against $\mathrm{C}^{\mathrm{w}} \mathrm{c}$ cells

It seems possible that in such natural mixtures the antibody or antibodies anti-G and anti- $\mathrm{C}^{\mathrm{w}}$ are on the same molecule. If an artificial 
mixture is made by adding the pure anti- $\mathrm{C}^{\mathrm{w}}$ serum (yet to be described) to a pure anti-C serum, the separation by absorption with $\mathrm{Cc}$ or $\mathrm{C}^{\mathrm{w}} \mathrm{c}$ is specific (fig. 2).

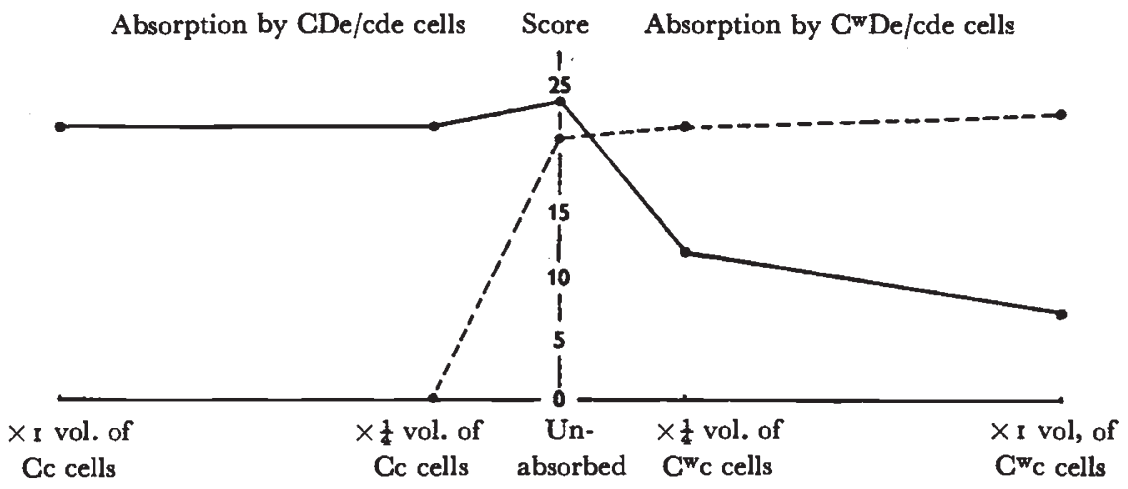

Frc. 2.-Absorption of an artificial mixture of pure anti-Cw ("Willis") and pure anti-C

(" $\mathrm{Br}$ ") by $\mathrm{CDe} /$ cde cells and by $\mathrm{Cw}$ De/cde cells.

- - - titration score against $\mathrm{Cc}$ cells titration score against $\mathrm{C}^{\mathbf{w}} \mathrm{c}$ cells

In this case the two antibodies must be on separate molecules.

\section{THE SPECIFIC ANTIBODY ANTI-Cw}

Two examples are known of pure anti- $C^{w}$ antisera. One was made by a patient of genotype $\mathrm{CC}$ who was transfused with $\mathrm{C}^{\mathrm{w}} \mathrm{C}$ blood (Callender and Race, I946). The other was made by a Cc mother against her $\mathrm{C}^{\mathrm{w}} \mathrm{C}$ child who suffered from hæmolytic disease as a result (Lawler and van Loghem, 1947).

Anti- $\mathrm{G}^{\mathrm{w}}$ like anti-c gives a well-marked dosage effect. This was realised when a very rare type of blood, $\mathrm{C}^{\mathrm{w}} \mathrm{C}^{\mathrm{w}}$, was found (Callender and Race, I946).

\section{THE FREQUENCIES OF THE Rh GENE}

The $\mathrm{Rh}$ chromosome and gene frequencies in England are known with considerable accuracy. The frequencies given in table I were calculated by Fisher, using his maximum likelihood method (I946), from the results of tests on 2000 blood samples (Race, Mourant, Lawler and Sanger, 1948). The gene frequencies obtained by adding the frequencies of the chromosomes containing $\mathrm{C}$, or $\mathrm{c}$, or $\mathrm{C}^{\mathrm{w}}$, etc., are also shown in the table.

In a genotype the pairs of allelomorphic genes come together purely at random, according to their respective frequencies. For example, the gene frequency of $\mathrm{C}$ is $4^{\mathrm{I}} \cdot 9^{8}$ per cent. and of c $5^{6} \cdot 73$ per cent. The genotype Cc would be expected to occur with a frequency of $0.4198 \times 0.5673 \times 2=0.4763$ or 47.63 per cent. The observed frequency of Cc bloods in 1073 samples was $46 \cdot 78$ per cent. 
The combinations of linked genes within each chromosome are not at random according to their respective gene frequencies. For example, the frequency of $\mathrm{C}$ is $4 \mathrm{I} \cdot 9^{8}$ per cent., of $\mathrm{D} 58 \cdot 97$ per cent.

\section{TABLE I}

The $R h$ chromosome frequencies in England (from Race, Mourant, Lawler, and Sanger, 1948)

\begin{tabular}{|c|c|c|c|c|c|c|c|c|}
\hline CDe & . & . & - & - & . & $40 \cdot 75$ & per & cent. \\
\hline cde & • & ${ }^{\circ}$ & • & • & . & $3^{8 \cdot 86}$ & , & , \\
\hline cDE & • & . & - & . & . & 14.11 & , &, \\
\hline cDe & - & . & - & - & . & $2 \cdot 57$ & ," & , \\
\hline CwDe & . & - & - & . & • & $1 \cdot 29$ & , & ", \\
\hline cdE & - & - & $\cdot$ & . & . & $1 \cdot 19$ & ,' & , \\
\hline Cde & . & . & $\cdot$ & . & . & 0.98 & , & , \\
\hline CDE & . & . & . & . & . & 0.24 & , & , \\
\hline
\end{tabular}

$\mathrm{C}^{\mathrm{w}} \mathrm{de}$ is known to exist, but no example was found in the series of 2000 bloods on which these frequencies are based.

The $R h$ gene frequencies

\begin{tabular}{|c|c|c|c|c|c|c|c|c|}
\hline C & • & . & - & . & - & $4^{1} \cdot 9^{8}$ & er & cent \\
\hline c. & . & . & - & - & - & $56 \cdot 73$ & ," & , \\
\hline C.w & . & . & - & . & . & I.29 & ," & ", \\
\hline D & - & . & - & . & . & $58 \cdot 97$ & , & , \\
\hline d. & . & . & . & . & . & $4^{1} \cdot 03$ & , , & , \\
\hline E & . & . & . & $\cdot$ & · & I 5.54 & , & \\
\hline e. & . & . & . & . & . & $84 \cdot 46$ & , & \\
\hline
\end{tabular}

and of $\mathrm{E}_{15} 54$ per cent. If such combinations were at random the expected frequency of the chromosome CDE would be $0.4198 \times$ $0.5897 \times 0.1554=0.0385$ or 3.85 per cent. The actual frequency is 0.24 per cent. To take another example, the expected frequency of Cde would be 14.55 per cent., whereas the actual frequency is 0.98 per cent. The divergencies are always considerable; since the combinations are not what would arise by chance, it seems that preferences are shown for certain combinations of genes on a chromosome. These preferences may be summarised thus : a capital letter gene prefers one capital and one small letter gene as its fellows ; a small letter gene prefers two capitals or none at all. (CdE, in being so rare that it has not yet been isolated, is the only exception to this latter rule.)

The gene $\mathrm{C}^{\mathrm{w}}$ makes the same choice as $\mathrm{C}$ and not the choice of $\mathrm{c}$. That is to say, $C^{w} D e$ is relatively common and $C^{w} d e$ is very rare, only one example having been observed, while no example of $\mathrm{C}^{\mathrm{w}} \mathrm{DE}$ has been found.

The parallel between $\mathrm{C}$ and $\mathrm{C}^{\mathrm{w}}$ in their choice of partner genes on a chromosome is supported by the following figures. Samples of blood from ${ }_{2564}$ random people have been tested with the anti- $\mathrm{C}^{\mathrm{w}}$ serum ; I49I reported by Callender and Race (1946) and 1073 by Race, Mourant, Lawler and Sanger (1948). The ratio

$$
\begin{array}{rccc}
\text { of } & \mathrm{C}^{\mathrm{w}} \mathrm{De} / \mathrm{cde} & \text { to } & \mathrm{C}^{\mathrm{w}} \mathrm{de} / \mathrm{cde} \\
\text { was } & 26 & \text { to } & \mathrm{I}
\end{array}
$$


In the 1073 blood samples, the ratio

\begin{tabular}{|c|c|}
\hline of & $\mathrm{CDe} / \mathrm{cde}$ \\
\hline was & 354 \\
\hline
\end{tabular}

The two ratios appear to be of the same order.

These considerations all suggest that the index $\mathrm{w}$ is appropriately given to a capital $\mathrm{C}$. The antigenic relationship of $\mathrm{C}$ and $\mathrm{C}^{\mathrm{w}}$ also supports the use of the capital letter.

\section{THE ALLELOMORPH $c^{v}$}

It has already been said that of 284 blood samples tested with a range of anti-C sera, two gave discrepant results. Only one of the two donors (Mr W., Jun.) could be traced, and table 2 shows the reactions of his blood and that of his parents and brother. Fig. 3 shows their pedigree.

TABLE 2

Reactions of the red cells of the family carrying the $\mathrm{c}^{\mathrm{v}}$ gene with various anti-Rh sera

\begin{tabular}{|c|c|c|c|c|c|c|c|c|c|c|c|c|}
\hline Anti & $-D$ & $-E$ & $-e$ & $-\mathrm{C}^{\mathrm{w}}$ & $-\mathbf{c}$ & $\mid-C$ & $\begin{array}{l}-\mathrm{C} \\
(\mathrm{Ho})\end{array}$ & $\begin{array}{l}-\mathrm{CCw} \\
(\mathrm{Ba})\end{array}$ & $\begin{array}{l}-\mathrm{CCW}^{-} \\
\text {(Ed) }\end{array}$ & $\mid \begin{array}{l}-\mathrm{CCW} \\
(\mathrm{Pe})\end{array}$ & $\begin{array}{l}-\mathrm{CCCw} \\
\text { (And) }\end{array}$ & Genotype \\
\hline Mother & + & + & + & - & + & - & - & - & - & - & - & $\mathrm{cDE} / \mathrm{cde}$ \\
\hline Father . & + & + & + & - & + & - & + & + & - & - & + & $\mathrm{c}^{\mathrm{v} D E} / \mathrm{cde}$ \\
\hline $\mathbf{c}_{\text {son }}^{\mathbf{v} \text { propositus Ist }}$ & + & + & + & - & + & - & + & + & - & - & + & $\mathrm{c}^{\mathrm{vDE} / \mathrm{cde}}$ \\
\hline 2nd son & - & - & + & - & + & - & - & - & - & - & - & cde/cde \\
\hline $\begin{array}{l}C^{u} \text { propositus for } \\
\text { comparison }\end{array}$ & + & - & + & - & + & - & - & - & - & + & + & $\mathrm{Cu}$ De/cde \\
\hline
\end{tabular}

Without the evidence provided by the younger brother, the propositus and his father ( $\mathrm{Mr}$ W., Sen.) would have been called

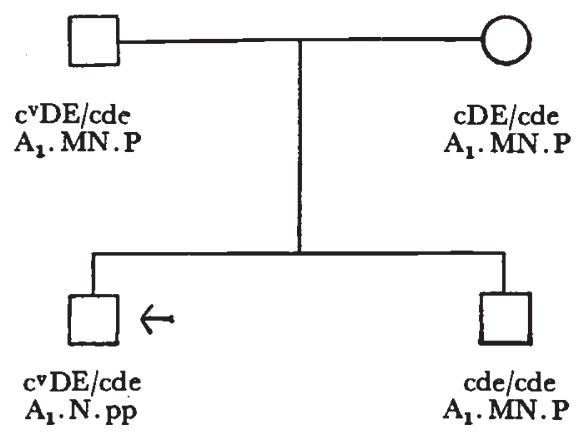

Fig. 3. - The blood groups of the $c^{v}$ family $\leftarrow=$ propositus

" $\mathrm{C}^{v} \mathrm{De} / \mathrm{cDE}$," for we were thinking of " $\mathrm{C}^{\mathrm{v}}$ " as being allied to $\mathrm{C}$, and while CDe is the most frequent of chromosomes, $\mathrm{CDE}$ is extremely 
rare. We would have guessed that the gene $\mathrm{E}$ was on the chromosome and, lacking anti-d serum, that the third gene on this chromosome was $\mathrm{D}$, for the combination $\mathrm{cDE}$ is frequent and cdE rare. Doubt would have been thrown on the presence of two D in the blood, however, for a weak anti-D serum in our possession is unusual in giving a fairly reliable dosage effect ; with the blood of the propositus it gave a clear-cut single dose effect. However, it was not necessary to rely on this dosage effect, for the blood of the younger brother made the family genotypes clear; one of the father's chromosomes was cde and therefore the "new" gene was carried on the other, in company with $\mathrm{D}$ and $\mathrm{E}$, and the genotypes of both the father and the eldest son were " $\mathrm{G}^{\mathrm{v}} \mathrm{DE} / \mathrm{cde}$."

Since the chromosome frequency of CDE is only 0.24 per cent., the frequency of a rare form of $\mathrm{C}$ together with $\mathrm{D}$ and $\mathrm{E}$ on one chromosome must be too small to consider the possibility of it being a chance combination. " $\mathrm{G}^{\mathrm{v}}$ " was making the choice of partners that would have been made by $\mathrm{c}$ and not by $\mathrm{C}$, and this interpretation received strong support in the following titrations of the two rare bloods with anti-c sera (fig. 4). The cells of the father gave a double dose effect and those of the elder son an effect certainly greater than that of a single dose of $c$.

In spite of the fact that the new allelomorph is agglutinated by some anti-G sera, we are compelled to call it $\mathrm{c}^{\mathrm{v}}$ and not $\mathrm{C}^{\mathrm{v}}$ for the two reasons already given and which may be summarised as follows :-

(i) Although the red cell antigen $c^{v}$ is agglutinated by 3 out of the 6 anti-C sera with which it was tested, it is also agglutinated by all of three anti-c sera, as proved by the double dose effect.

(ii) The fellow genes on the $c^{v}$ chromosome are those which partner $c$ and not $\mathrm{C}$.

We are forced to the conclusion that the three anti-c sera used are really anti-c $+c^{v}$; as in the case of the anti- $\mathrm{C}+\mathrm{C}^{\mathrm{w}}$ sera, it must be supposed that the anti-c component is a "non-specific" response to the antigen $c$. It is quite beyond the bounds of possibility that the three donors of the anti-c sera were immunised by $c^{v}$ as well as c.

We must also conclude that three of the six anti- $\mathrm{C}$ sera used are anti- $\mathrm{C}+\mathrm{c}^{\mathrm{v}}$, the anti-c component again being a "non-specific" response, this time to the antigen $\mathrm{C}$.

That anti-C $+\mathrm{c}^{\mathrm{v}}$ is one antibody or at any rate on one molecule is strongly suggested by the graph (fig. 5). This graph shows the effect of absorbing one of the anti- $\mathrm{C}+\mathrm{c}^{\mathrm{v}}$ sera, " $\mathrm{Ba}$," with the cells of the elder son who is $\mathrm{c}^{\mathrm{v}} \mathrm{DE} / \mathrm{cde}$, and absorbing some more of the same serum with control $\mathrm{CDe} /$ cde cells. Three absorptions of the serum were done with each type of cell, one volume of the serum being absorbed with $\frac{1}{4}, \frac{1}{2}$ and an equal volume of packed cells. The 
serum was titrated before absorption, and after each of the six absorptions, against both types of cell.
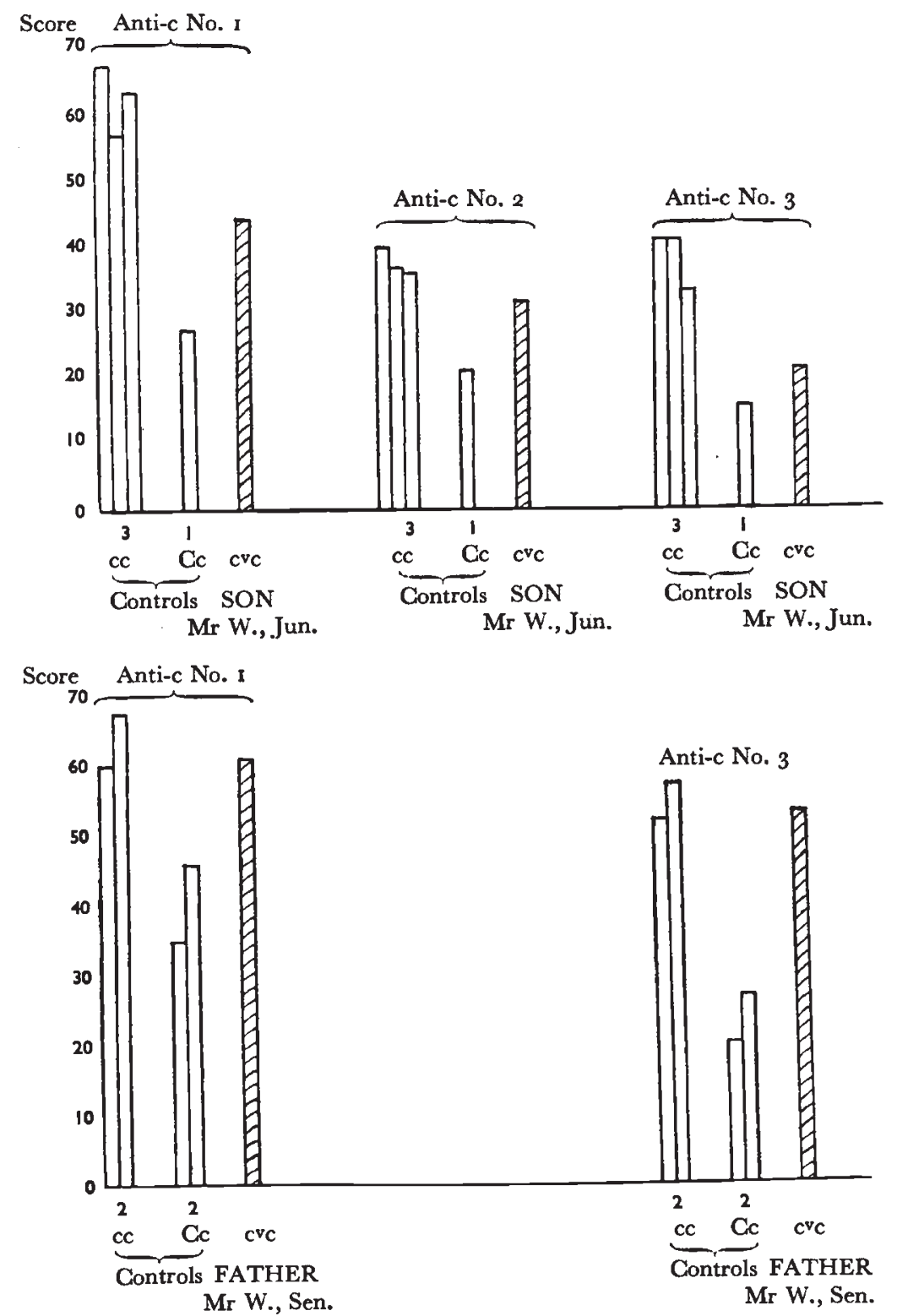

Fig. 4.-Showing that $\mathrm{c}^{\mathrm{v}} \mathrm{C}$ blood does not give a single dose effect when titrated with anti-c sera.

It will be seen from the graph that the $c^{v} \mathrm{DE} / \mathrm{cde}$ cells absorb both anti-C and anti-c" from " $\mathrm{Ba}$ " serum and that the $\mathrm{CDe} / \mathrm{cde}$ cells also absorb both anti-C and anti-c" ${ }^{\mathrm{v}}$. It also appears that, within the limits of experimental error, the two types of cells are equally efficient in removing antibody. 
It appears that the haploid antigen $\mathrm{c}^{\mathrm{v}}$ has something in common with $\mathrm{c}$ and also with $\mathrm{C}$, and one may picture the allelomorphs at this locus as a series of perhaps minor modifications of some basic substance

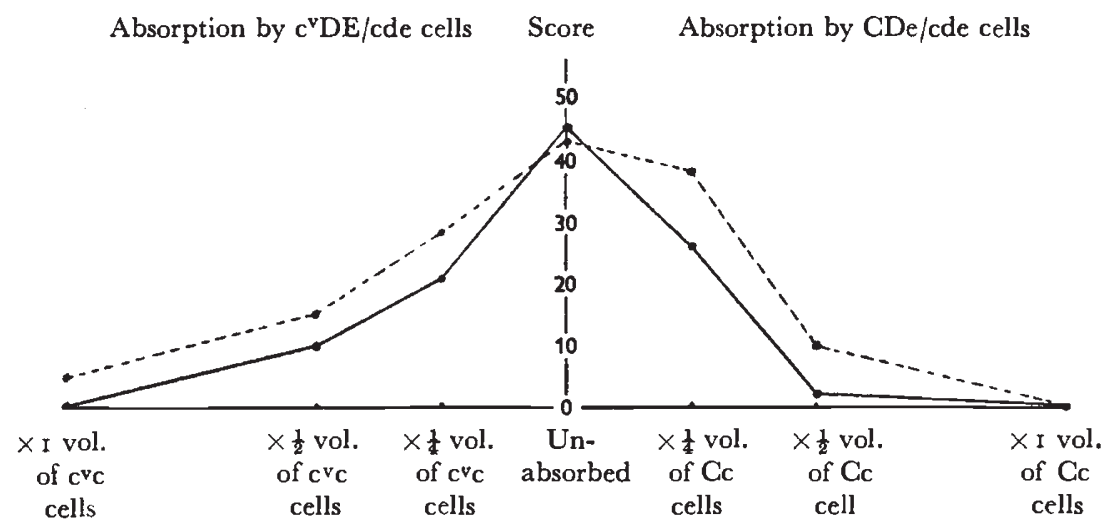

Fig. 5.-Anti-C (" $\mathrm{Ba}$ ") absorbed by c" $\mathrm{DE} / \mathrm{cde}$ cells and by $\mathrm{CDe} /$ cde cells.

- - - titration score against Cc cells

titration score against $\mathrm{c}^{\mathbf{v}} \mathrm{c}$ cells

passing from $\mathrm{c}$, through $\mathrm{c}^{\mathrm{v}}$ to $\mathrm{C}$. The reactions of these three haploid antigens with the various antisera are represented diagrammatically in fig. 6. The antigen $\mathrm{C}^{\mathrm{u}}$, yet to be described, and the antigen $\mathrm{C}^{\mathrm{w}}$

Agglutination range of antisera

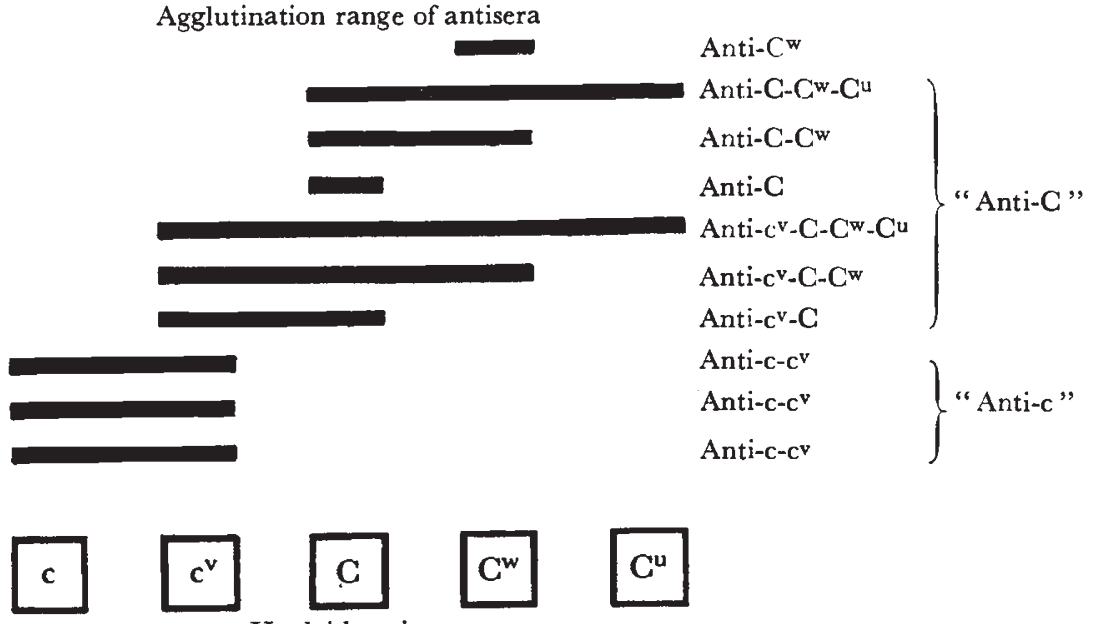

Haploid antigens

FIG. 6. The reactions of the antigens allelomorphic to $\mathrm{C}$ with their antisera.

can also be fitted into line. Although there is no obvious reason why the modifications should be representable in a linear order, in one dimension, nevertheless they can be so arranged. If an antibody was found which reacted with say $\mathrm{C}$ and $\mathrm{C}^{\mathrm{u}}$, but not $\mathrm{C}^{\mathrm{w}}$, another dimension would be needed in which to rearrange the antigens. This would also apply if another antigen was found which reacted with anti- $\mathrm{C}+\mathrm{C}^{\mathrm{u}}$ and with anti-C but not with anti- $\mathrm{C}^{\mathrm{w}}$. 


\section{THE ANTIGEN Cu}

As has already been mentioned, the donor of this blood could unfortunately not be traced, and therefore the inheritance of this antigen could not be studied. It seems reasonable to suppose, however, that it represents a fifth allelomorph at the locus.

The reactions of $\mathrm{C}^{\mathrm{u}}$ are summarised in fig. 6 , and are given in more detail in table 3 where the results are shown of titrating various types of red cells against the six anti- $\mathrm{C}$ sera and one pure anti- $\mathrm{C}^{\text {w }}$ serum.

\section{TABLE 3}

Examples of agglutination reactions of the antigens controlled by the $\mathrm{G}-\mathrm{c}$ locus

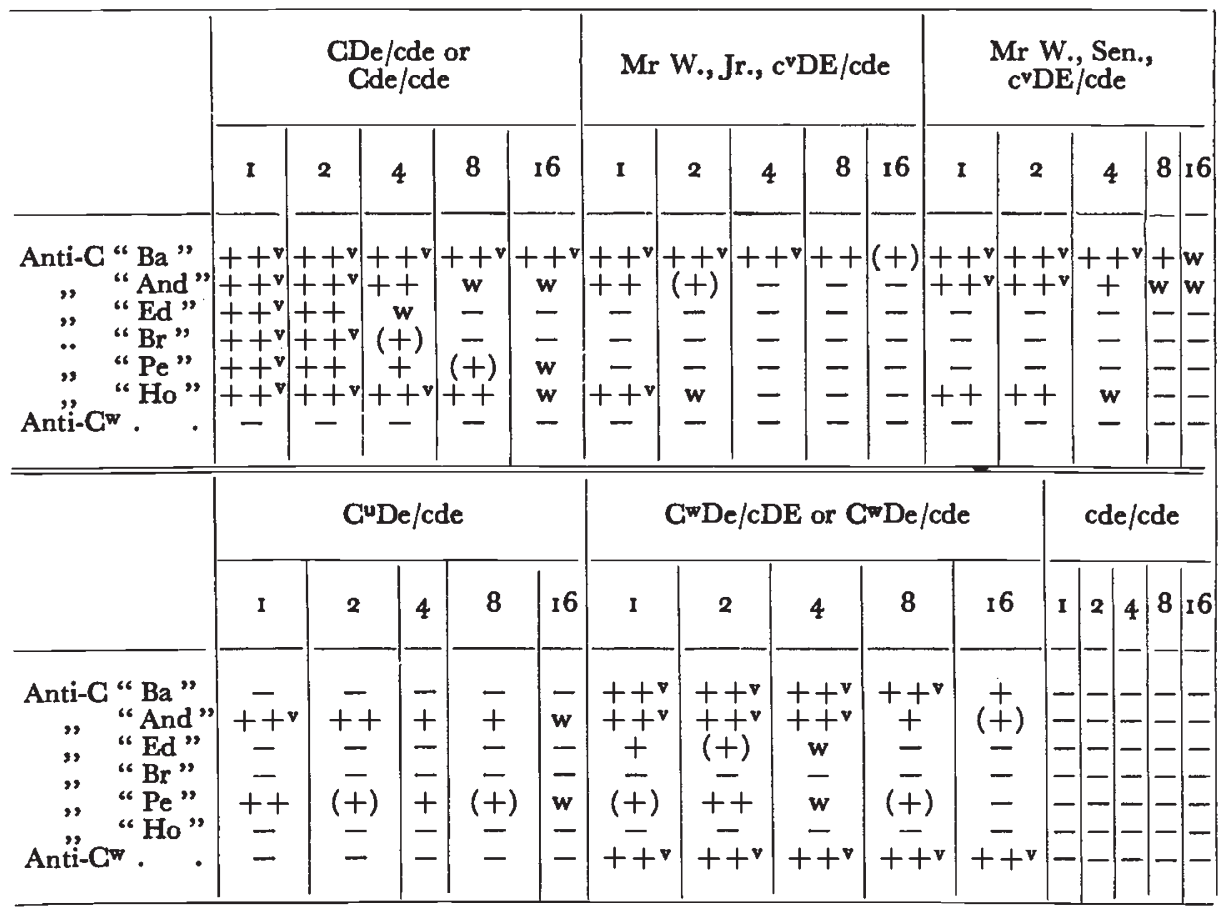

$++v,++,+,(+), w-$ represent decreasing amounts of agglutination

The scope of antibody is not merely an expression of the strength of anti-C agglutinin which it contains; in table 3 it will be seen that the powerful serum " $\mathrm{Ba}$ " fails to agglutinate the $\mathrm{C}^{u}$ blood which is agglutinated by the less powerful anti-C sera "Pe" and "And."

\section{THE FREQUENCIES OF THE ALLELOMORPHS AT THE C LOCUS}

From the results of the tests on the 284 blood samples a rough estimate of the frequency of the allelomorphs at this locus may be 
made by merely adding each type of gene in the following list of the observed genotypes (table 4 ).

TABLE 4

Frequency of genes at the $\mathrm{C}$ locus in 284 English men

\begin{tabular}{|c|c|c|c|c|c|c|c|c|c|}
\hline & \multicolumn{7}{|c|}{ GENOTYPES } & \multicolumn{2}{|c|}{ GENES } \\
\hline & crc & $\mathrm{C}^{\mathbf{u}} \mathrm{c}$ & Cc & $\mathrm{Cw}^{\mathrm{w}} \mathrm{c}$ & $\mathrm{C}^{\mathrm{w}} \mathrm{C}$ & CC & cc & Total & $\begin{array}{l}\text { per } \\
\text { cent. }\end{array}$ \\
\hline & crDE/cde I & CuDe/cde I & $\begin{array}{lr}\text { CDe/cde } & 85 \\
\text { CDe/cDE } & 43 \\
\text { Cde/cde } & 3 \\
& \\
& \\
1_{3}\end{array}$ & 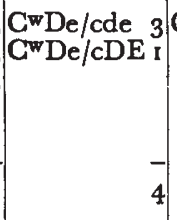 & $\begin{array}{r}\text { CwDe/CDe } 3 \\
- \\
3\end{array}$ & $\begin{array}{r}\mathrm{CDe} / \mathrm{CDe}{ }_{4} \\
\mathrm{CDe} / \mathrm{CDE}{ }_{2} \\
\frac{4 \varepsilon}{4}\end{array}$ & $\begin{array}{l}\text { 6de/cde } \\
2 \mathrm{cDE} / \mathrm{cDE} \\
\mathrm{cDE} / \mathrm{cde} \\
\mathrm{cdD} / \mathrm{cde} \\
\mathrm{cDe} / \mathrm{cde} \\
\\
\end{array}$ & & \\
\hline $\begin{array}{l}\mathbf{c}^{\mathrm{v}} \\
\mathrm{C}^{\mathrm{u}} \\
\mathrm{C} \\
\mathrm{c} \\
\mathrm{C}^{\mathbf{w}}\end{array}$ & $\begin{array}{c}\text { I } \\
\ldots \\
\ldots \\
I \\
\ldots\end{array}$ & $\begin{array}{l}\ldots \\
\mathbf{I} \\
\ldots \\
I \\
\cdots\end{array}$ & $\begin{array}{c}\ldots \\
\ldots \\
\text { I } \text { I } \\
\text { I } \mathrm{I} \\
\ldots\end{array}$ & $\begin{array}{l}\cdots \\
\cdots \\
\ldots \\
4 \\
4\end{array}$ & $\begin{array}{c}\ldots \\
\ldots \\
3 \\
3 \\
3\end{array}$ & $\begin{array}{l}\ldots \\
\ldots \\
96 \\
\ldots \\
\cdots\end{array}$ & $\begin{array}{c}\ldots \\
\ldots \\
\ldots \\
192 \\
\ldots\end{array}$ & $\begin{array}{r}1 \\
1 \\
230 \\
329 \\
7\end{array}$ & $\begin{array}{r}0 \cdot 18 \\
o \cdot 18 \\
40 \cdot 49 \\
57 \cdot 92 \\
r \cdot 23\end{array}$ \\
\hline & & & & & & & & 568 & $100 \cdot 00$ \\
\hline
\end{tabular}

It must be remembered that $\mathrm{C}^{\mathrm{u}}$ would not be recognised in the combination $\mathrm{C}^{\mathrm{u}} \mathrm{C}$ and perhaps one has been missed in the $48 \mathrm{CG}$ bloods. In the $43 \mathrm{CDe} / \mathrm{cDE}$ bloods the genotypes $\mathrm{CDe} / \mathrm{c}^{\mathrm{v}} \mathrm{DE}$ could not have been distinguished and the genotype $\mathrm{CDe} / \mathrm{c}^{\mathrm{v}} \mathrm{de}$ could have been hidden in the $85 \mathrm{CDe} / \mathrm{cde}$ bloods. It should perhaps be mentioned that the finding of $2 \mathrm{CDe} / \mathrm{CDE}$ in only 284 samples of blood is by chance rather an unusual one ; we expect only 2 in 1000 English blood samples.

The estimates of the gene frequencies based on this small sample show very close agreement with the more accurate estimates of table I which are based on 2000 samples.

\section{DISCUSSION}

The exact relationship of the various $\mathrm{C}$ antigens to their antibodies presents, rather clearly, a fundamental question of serology. It seems still to be a matter of argument whether a multiplicity of antibodies made to an antigen of necessity reflects a multiplicity of determinant groups in that antigen. According to the alternative view, an antigen may evoke antibodies not only to the determinant groups which it does possess, but also to others, doubtless similar in structure, but which it does not possess.

There are therefore at least two ways of interpreting the antigenantibody reactions described in this paper. 
I. We may suppose that the antigen $G$ contains all the determinant groups to which it may stimulate antibody. That is to say, it contains $\mathrm{C}, \mathrm{C}^{\mathrm{w}}, \mathrm{C}^{\mathrm{u}}$ and $\mathrm{c}^{\mathrm{v}}$, and other, as yet unrecognised, components. We know that the response to immunisation by $\mathrm{C}$ is variable, sometimes being anti-C, sometimes anti-C $+\mathrm{C}^{\mathrm{w}}$, sometimes anti-C $+\mathrm{C}^{\mathrm{w}}+\mathrm{c}^{\mathrm{v}}$, etc., and this variability we could attribute to varying amounts of the different components in the antigen. Alternatively it could be attributed to individual peculiarities of the person immunised. The variability of response might be due to the presence in different $\mathrm{C}$ antigens of different combinations of the antigens $\mathrm{C}^{\mathrm{w}}, \mathrm{C}^{\mathrm{u}}$ and $\mathrm{c}^{\mathrm{v}}$, etc. That is to say, while supposing that a particular antigen $\mathrm{C}$ always contains the other antigens to which it stimulates antibodies, it may not necessarily be thought to contain the whole set.

On this view the linear order in which the haploid antigens can be arranged (fig. 6), if it is not fortuitous, might be interpreted as an indication of relationships, not necessarily spatial, within the gene. At least it would be an indication of differentiation within the gene.

A serious difficulty, not easily reconciled with this view is the fact that although $\mathrm{G}$ usually stimulates the antibody anti- $\mathrm{C}+\mathrm{C}^{\mathrm{w}}$, yet homozygous CG cells consistently fail to be agglutinated by the pure anti- $\mathrm{C}^{\mathrm{w}}$ serum, although this agglutinin is a powerful one. If haploid $\mathrm{C}$ contains enough $\mathrm{C}^{\mathrm{w}}$ component to produce anti- $\mathrm{C}+\mathrm{C}^{\mathrm{w}}$, one would expect diploid CG cells to have enough $\mathrm{C}^{\mathrm{w}}$ to be agglutinated by anti-C.

2. From a fundamentally different viewpoint, we may consider that $\mathrm{C}$ is one single antigen and that when it evokes, for example, the antibody anti-C $+C^{w}$, the anti- $C^{w}$ component is an extra or "non-specific" response. By this we mean that an antibody has been made to a substance not present in the provocative antigen though probably chemically similar to this antigen.

It seems to have been in this light that Landsteiner and van der Scheer interpreted the results of their experiments when using pure meta-amino benzene sulphonic acid as an antigen. The response to this antigen was not only anti-meta-amino benzene sulphonic acid but also anti-ortho-amino benzene sulphonic acid, anti-meta-amino benzene arsenic acid and anti-meta-amino benzoic acid. While allowing the existence of antigens with several determinant groups in one molecule, Landsteiner and van der Scheer considered that this could not apply to meta-amino benzene sulphonic acid owing to the simplicity of its structure. These authors drew the same conclusions from the results of using other chemically simple antigens.

Morgan (1937) has pointed out that in some of the antigens used in the experiments of Landsteiner and van der Scheer, there are certain chemical structures which are also present in the antigens corresponding to the "non-specific" components of the antibody. Morgan therefore considers that the results obtained by these 
investigators are probably to be explained according to the view summarised in ( $\mathrm{I}$ ).

According to this view (2), the linear order in which the antigens can be arranged in fig. 6 , if it is of significance, may indicate progressive stepped mutations of the gene; it does not seem to suggest differentiation within the gene.

According to either view it would seem that the different antigens are closely related chemically, and it is substances closely related to $\mathrm{C}$ that we would expect genes allelomorphic to $\mathrm{C}$ to produce ; witness the close chemical similarity of the $\mathrm{A}, \mathrm{B}$ and $\mathrm{O}$ blood group substances (Morgan, 1947).

Whatever may be the true view of the origin of the antibodies they only become recognisable when a gene capable of producing the equivalent antigen is found.

\section{SUMMARY}

Evidence is presented for the existence of two further allelomorphs at the c-C-Cw locus of the $\mathrm{Rh}$ chromosome in man. One of the new allelomorphs, $c^{v}$, is present in two generations of the family in which it was recognised. In this family the chromosome combination is $c^{v} \mathrm{DE}$.

The antigen $\mathrm{c}^{\mathrm{v}}$ has something in common with $\mathrm{C}$ and with $\mathrm{c}$, in that it reacts with certain anti-C sera and all of three anti-c sera. A small $\mathrm{c}$ is considered the more appropriate notation for the gene $c^{v}$, for $\mathrm{cDE}$ is a common chromosome in England, and CDE an extremely rare one.

The evidence for the fifth allelomorph $\mathrm{C}^{\mathrm{u}}$ is somewhat incomplete, for although the antigen is serologically distinct, the family of the donor in whose blood it was found was not available.

The relationships of the various antibodies to the antigens controlled by the $\mathrm{C}$ allelomorphs are discussed.

Acknowledgments.-We wish to thank Dr J. Loutit and the members of his staff at the National Blood Transfusion Service, South Western Region, Sutton, Surrey, for supplying us with the 284 samples of blood on which this investigation was based. For the antisera used in the investigation we are indebted to Dr Mourant of the Ministry of Health Blood Group Reference Laboratory, and also to the following : Dr E. F. Aubert, Dr Sheila Callender, Professor D. F. Cappell, Dr D. S. Dick, Dr R. J. Drummond, Mr I. Dunsford, Dr A. J. McGall, Dr Brenda Morrison, Dr John Murray, Dr Anne Sandison, Dr W. S. Stanbury and Dr R. A. Zeitlin.

\section{REFERENCES}

CALLENDER, S., AND RACE, R. R. 1946.

A serological and genetical study of multiple antibodies formed in response to blood transfusion by a patient with lupus erythematosus diffusus.

Ann. Eugen. 13, 102-1 I7.

FISHER, R. A. 1946.

The fitting of gene frequencies to data on rhesus reactions.

Ann. Eugen. 13, 150. 
FISHER, R. A., cited by RACE, R. R. 1944 .

An " incomplete" antibody in human serum.

Nature, Lond. 153, 77 I-772.

PISHER, R. A., AND RACE, R. R. I946.

$\mathrm{Rh}$ gene frequencies in Britain.

Nature, Lond. $157,4^{8}$.

LANDSTEINER, K., AND SGHEER, J. VAN DER. 1936.

On cross reactions of immune sera to Azoproteins.

7. Exp. Med. 63, 325 .

LAWLER, S. D., AND LOGHEM, J. J. VAN. 1947.

The rhesus antigen $\mathrm{C}^{\mathrm{w}}$ causing hæmolytic disease of the newborn.

Lancet 2, 545 .

MORGAN, W. T. J. 1937.

A conception of immunological specificity.

F. Hyg. $37,372$.

MORGAN, W. T. J. 1947.

The human $\mathrm{ABO}$ blood group substances.

Experientia 3, 257.

RAGE, R. R., MOURANT, A. E., LAWLER, S. D., AND SANGER, R. 1948.

The $\mathrm{Rh}$ chromosome frequencies in England.

Blood, The Journal of Hematology, 3, 689-695.

RACE, R. R., TAYLOR, G. L., BOORMAN, KATHLEEN E., AND DODD, BARBARA E. 1943.

Recognition of $\mathrm{Rh}$ genotypes in man.

Nature, Lond. 152, 563-564. 